\title{
Archaeological Survey and Backhoe Testing for Flume No. 3 Right-of-Way at Coleto Creek Reservoir, Goliad County, Texas
}

Kenneth M. Brown

Follow this and additional works at: https://scholarworks.sfasu.edu/ita

Part of the American Material Culture Commons, Archaeological Anthropology Commons, Environmental Studies Commons, Other American Studies Commons, Other Arts and Humanities Commons, Other History of Art, Architecture, and Archaeology Commons, and the United States History Commons

Tell us how this article helped you.

This Article is brought to you for free and open access by the Center for Regional Heritage Research at SFA ScholarWorks. It has been accepted for inclusion in Index of Texas Archaeology: Open Access Gray Literature from the Lone Star State by an authorized editor of SFA ScholarWorks. For more information, please contact cdsscholarworks@sfasu.edu. 
Archaeological Survey and Backhoe Testing for Flume No. 3 Right-of-Way at Coleto Creek Reservoir, Goliad County, Texas

\section{Creative Commons License}

\section{(c) (1) \&}

This work is licensed under a Creative Commons Attribution-NonCommercial 4.0 International License 


\section{Archaeological Survey And Backhoe Testing For FLUME NO. 3 RIGHT-OF-WAY AT COLETO CREEK RESERVOIR, Goliad County, Texas}



\section{Kenneth M. Brown}

Center for Archaeological Research The University of Texas at San Antonio Archaeological Survey Report, No. 128 

ARCHAEOLOGICAL SURVEY

AND BACKHOE TESTING FOR

FLUME NO. 3 RIGHT-OF-WAY

AT COLETO CREEK RESERVOIR,

GOLIAD COUNTY, TEXAS

Kenneth M. Brown

Texas Antiquities Committee Permit No. 80

Thomas R. Hester, Principal Investigator

Center for Archaeological Research The University of Texas at San Antonio ${ }^{\circledR}$ Archaeological Survey Report, No. 128 
The following information is provided in accordance with General Rules of Practice and Procedure, Chapter 41.11 (Investigation Reports), Texas Antiquities Committee:

1. Type of investigation: archaeological survey and backhoe testing;

2. Project name: Coleto Creek Flume No. 3;

3. County: Goliad, Texas;

4. Principal Investigator: Thomas R. Hester;

5. Name and location of sponsoring agency: Guadalupe-Blanco River Authority, Seguin, Texas;

6. Texas Antiquities Committee Permit No. 80;

7. Published by the Center for Archaeological Research. The University of Texas at San Antonio, San Antonio, Texas 782850658;

8. Date of publication: 1986.

A 1 ist of pub 1 ications offered by the Center for Archaeological Research can be obtained by sending $\$ 1.00$ to the Center for Archaeological Research, The University of Texas at San Antonio, San Antonio, Texas 78285-0658. 


\begin{abstract}
During August 1983, archaeological survey and testing were conducted at Flume No. 3 for the Col eto Creek power plant reservoir in Gol lad County, Texas. The work included survey of the entire $F 1$ ume No. 3 route, testing one site (41 GD 30B) located at the flume outlet on Coleto Creek, survey and testing of an alternate flume route downstream, and testing at another site designated 41 GD 31. The right-of-way survey revealed a historic site (41 GD 48) in the proposed spoil area; no further work is recommended at this site. Testing at 41 GD $30 \mathrm{~B}$ provided necessary additional information on the site's area and depth. It was judged that the flume outflow could damage the integrity of the site, and that the site should be avoided or the impact mitigated. Survey and testing of the alternate, downstream flume route indicated this route provides the best alternative for reservoir outflow since no cultural resources were found on the surface and a possible buried component at 41 GD 31 would probably be too deeply buried to be affected.
\end{abstract}

KEYWORDS: Berger Bluff archaeological site, Angostura point, historic site, Coleto Creek Reservoir, Goliad County. 


\section{TABLE OF CONTENTS}

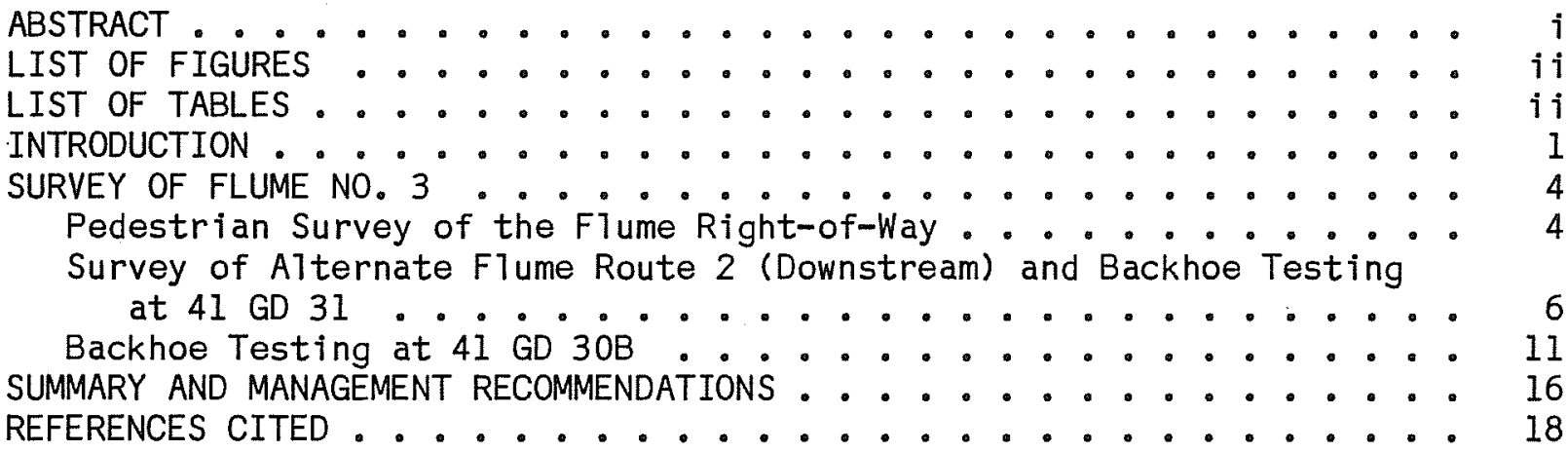

\section{LIST OF FIGURES}

1. Coleto Creek Reservoir, Showing Location of Flume No. 3 and Sites

Discussed in the Text ..................... 2

2. Map Showing Coleto Creek Outfall of Flume No. 3, with Archaeo-

logical Sites 41 GD 29, 41 GD 30 (Berger Bluff), and 41 GD 31 . . 5

3. Artifacts from 41 GD 30, 41 GD 31, and 41 GD 48 . . . . . . . . . . 9

4. Profiles of Backhoe Trenches 2 and 3 at 41 GD 30B . . . . . . . . . 15

5. Cross Sections of Geologic Units at the Berger Bluff Site

17

\section{LIST OF TABLES}

1. Backhoe Trenches at $41 \mathrm{GD} 30 \mathrm{~B} \ldots$................... 13 


\section{INTRODUCTION}

During August 1983, archaeologists from the Center for Archaeological Research (CAR), The University of Texas at San Antonio (UTSA), conducted survey and backhoe testing for the proposed Flume No. 3 right-of-way, including the alternate downstream flume route and testing at two sites, $41 \mathrm{GD} 30 \mathrm{~B}$ and $41 \mathrm{GD} 31$, at Coleto Creek Reservoir in Goliad County, Texas.

The survey and testing were done under the terms of a contract between the Center for Archaeological Research and the Guadalupe-B1anco River Authority (1etter from David Welsch dated June 27, 1983), in compliance with the National Historic Preservation Act of 1966 (as amended) and its implementing regulations, 36CFR800; the Nationa1 Environmenta 1 Policy Act of 1969; and Executive Order 11593. The field work was done by Kenneth M. Brown, research associate, and technical staff assistants Ralph Snavely and Charles Suhler. Overall 1 supervision was provided by Dr. Thomas R. Hester, CAR director, and Jack D. Eaton, associate director. Field notes, photographs, and artifacts collected during the project are housed at the CAR.

Coleto Creek Reservoir was completed in 1980 by the Guada1upe-B1anco River Authority (GBRA) to serve as a cooling reservoir for a coal-fired power generating plant operated by Central Power and Light Company. The addition of a second power plant, scheduled for completion by 1989, wi11 require additional water recirculating capacity to maintain the thermal gradient in the reservoir, and consequent1y the GBRA plans to construct a 1 arge, open canal (designated Flume No. 3) leading from Turkey Creek northeast to Coleto Creek. The flume has no gradient, but under normal flow conditions in the watershed, discharge is expected to be southwest to northeast into Coleto Creek. The planned route of the flume fol 1 ows a 1 ong, straight tributary drainage of Turkey Creek on a north-northeast azimuth as far as Coletoville Road, then continues on a northeasterly course to join another ravine which enters Coleto Creek at Berger Bluff (Fig. 1).

The flume right-of-way is $3.08 \mathrm{~km}$ ( $1.9 \mathrm{miles}$ ) 1ong, extending from the norma 1 pool level at 98 feet MSL (above mean sea leve1) at each end, and is $120 \mathrm{~m}$ wide, flanked on each side by an access road and drainage ditch. Because the floor of the flume is level (at 89 feet MSL), with a constant gradient to the sides, the width and depth wil1 vary with topography, from about 25-100 m across and up to $15 \mathrm{~m}$ deep. Fill from excavation is to be placed in a spoil disposal area $380 \mathrm{~m}$ wide running the length of the flume on the southeast side, bordered by a drainage ditch on the southeast side. The area to be affected is thus $3.08 \mathrm{~km}$ long by $390 \mathrm{~m}$ wide, or about 120 hectares.

Previous archaeological work in the project area has been done by the Center for Archaeological Research. The University of Texas at San Antonio. In 1975, a phase 1 survey of the reservoir was done (Fox and Hester 1976); in 1976, surveys of the water supply pipeline from the Guadalupe River to Coleto Creek, a Highway 59 relocation, and a railroad spur right-of-way were done; in 1977, phase 2 testing of selected sites, including Berger B1uff (4I GD 30) and 41 GD 31 was done (Fox, B1ack, and James 1979); testing, architectural recording, and historical research on the Steiner and Schob sites were done (Fox and Livingston 1979); in 1977-1978, excavation for impact mitigation was done at 41 GD 21 (D. Fox 1979), and in 1979, at Berger Bluff in the upper 
This page has been

redacted because it

contains restricted

information. 
deposits (Brown 1983), and later in the lower deposits (the "bench project"). Other recent projects include recovery of a prehistoric burial at the Victoria Regiona 1 Wastewater Treatment P1ant (Potter and Spencer 1980) and survey and shovel testing of a proposed park trail at Victoria Municipal Park (Taylor 1985).

The research to date on the Berger Bluff site, most of which has been concentrated in Area $A$, has shown it to be an exceptionally important prehistoric site. As a deeply stratified site with a long record of human occupation and environmental indicators it is essentially unique on the Texas coastal plain. Here over $8.5 \mathrm{~m}$ of deposits forming a steep bluff along Coleto Creek contain stratified Late Archaic to Late Prehistoric (ca. 2000700 B.P.) cultural debris in the upper part; the lowest, or "bench" deposits contain sparse cultural debris of 1 ate Pleistocene or early Holocene age. Two radiocarbon dates from these lower deposits, $11,550 \pm 800$ B.P. and $7770 \pm$ 810 B.P., are in disagreement, and efforts are underway to complete additional radiocarbon or thermoluminescent analyses to resolve the age of the early deposits. If the 11.550 B.P. date is valid, it represents the oldest, or one of the oldest radiocarbon dated human occupations in south Texas. Earlier radiocarbon dates on soil samples are known from a site on Petronila Creek in Nueces County, but how these dates relate to cultural debris at the site is not yet clear (Bob Lewis, personal communication).

In any case, the early deposits, a fossilized spring-margin site, seem to represent a period of somewhat greater effective moisture than now, with a more equable annual distribution of rainfal1, probably 1 acking the seasona 1 extremes of temperature and precipitation characteristic of most of the Holocene. The up 1 ands, now in post oak-1 ive oak forest/savanna, may have been much the same, but the creek valley was probably much more verdant, with Coleto Creek a rather muddy, meandering stream, deeper, narrower, and with much less flashy discharge than now. The site was occasionally visited by foraging groups of prehistoric Indians, one of which appears to have left the remains of smal1 rodents, salamanders, snakes, fish, and birds near the sma 11 fire hearth that provided the earliest radiocarbon date Research on this microfauna deposit was begun in 1982, funded by a grant from the Texas Archeological Foundation.

Information on environmental change comes chiefly from geologic studies of the sediments and their organic carbon content, from identification of microscopic snails (over 30 taxa have been identified), from studies of the microfauna, and from a few clues of lesser abundance, such as plant pollen (poorly preserved), species identification of charcoal and of freshwater mussel she11, and distribution studies of fossilized plant remains.

The paramount importance of the Berger Bluff site 1 ies in the fact that it seems to contain an unbroken record of environmental change and human occupation that spans most of south Texas' human prehistory. Although the middle $4.5 \mathrm{~m}$ of deposits are unsampled and have never been closely examined, I believe the stratigraphic section represents continuous aggradation with no erosional hiatuses. Many other important stratified sites in south Texas or the Lower Pecos region, such as Arenosa Shelter (Dibble 1967), have had deposits removed at intervals by scouring, or do not represent as early a period, or 1 ack as complete a range of environmental indicators (e.g., 
41 LK 31/32, Scott 1982; the Johnston-Hel ler site, Birmingham and Hester $1976)$.

\section{SURVEY OF FLUME NO. 3}

In May 1983, the GBRA requested a proposal to provide archaeological survey and testing of the flume right-of-way. The proposed work entailed three aspects:

(1) pedestrian survey of the planned flume right-of-way;

(2) pedestrian survey of alternate route 2 (a more easterly route for the exit end, discharging downstream from Berger Bluff) and backhoe testing at $41 \mathrm{GD} 31$, another site with a possible Late Paleo-Indian component near the outfal1; and

(3) backhoe testing at Area $B$ of the Berger Bluff site to determine its spatial limits and depth (Fig. 2).

\section{Pedestrian Survey of the Flume Right-of-Way}

The flume survey was done August 8-12, 1983, by Brown, Snavely, and Suhler, and on August 16-17 by Brown and Snavely. Straight-1 ine transects spaced 30-50 m apart were walked the length of the right-of-way, except where impeded by understory vegetation, when meandering transects were fol 1 owed. Most of the survey area, from sta. 30+00 to sta. 100+00, consists of post oak-live oak woodland ranging in density from open woodland to savannalike habitat. There is 1 ittle or no understory, and ground cover consists of sparse to heavy grasses; oak leaves and some areas of heavy grass cover were the principal obstruction to ground visibility over much of the area. Some low swales bear small huisache thickets. Most areas are in unimproved pasture, although a few areas appeared to have been partial 1y cleared of timber in the past. The previous statements apply essentially to the northeastern two-thirds of the right-of-way. The portion from sta. 0+00 to sta. 30+00, near Turkey Creek, has dense post oak woodland in most areas, choked with heavy, in some places nearly impenetrable understory. Particular difficulty was experienced in the area at the confluence of Turkey Creek and its southwest-draining tributary, on the east bank of the 1atter. Understory vegetation was found to be particularly troublesome immediately adjacent to drainages. One area at the confluence of this drainage and Turkey Creek was shove 1 tested twice to a depth of about $60 \mathrm{~cm}$ and screened through 1/4-inch mesh, but nothing was found; the area tested is about $30 \mathrm{~m}$ southwest of the turnaround for the west flume access road, at about 102 feet elevation.

One archaeological site (4I GD 48) was found during the survey, a sma11 surface scatter of 1 ate 19th-century artifacts located adjacent to the eastern boundary of the spoil disposal area, at 134 feet MSL, at the crest of the eroded Lissie terrace scarp where it begins to slope down to Coleto Creek. The site is about $335 \mathrm{~m}$ southwest of the creek, on the former Dietze 1 property. Surface features include a rectilinear pattern of four 1 arge Goliad sandstone blocks, probably foundation supports for a building, and a smal1 pit with some associated boards. Found on the surface were seven plain ironstone sherds (representing plates or saucers[?], cups, and probably a 
This page has been

redacted because it

contains restricted

information. 
teapot; Fig. 3,a,b); one plain porcelain rim sherd; eight clear, aqua (Fig. 3,c,d), or brown (beer/whiskey) bottle glass sherds; a clear glass sherd from a kerosene lamp chimney (Fig. 3,e); a riveted iron pot(?) fragment (Fig. 3,f); another smal1 cast iron fragment (Fig. 3,g); a 3/8-inch diameter iron rod 4-3/4 inches long ( $F i g .3, i)$; a large cast iron machinery part with stamped lettering "_BCPCO" and with the raised letters "Bl" below; a brass harness rivet (Fig. $3, h$ ); two small sawed animal bone fragments; six freshwater musse 1 she 11 fragments (three are Amb 1ema p 1 icata); and a hardwood batten with square (probably machine-cut) nails hammered into it. The assemblage appears to date from the $1880 \mathrm{~s}$ (Anne Fox, personal communication). Included in the bottle glass is a base sherd (Fig. 3,d) marked

L G CO

21

This is a logo used by the Louisville Kentucky Glass Works ca. 1880, and perhaps as 1ate as 1886, on handmade beer bott 1es (Tou 1ouse 1971:323-324). Also found on the surface were three prehistoric artifacts: a core remnant and two flake fragments. Presumably the mussel shell is historic rather than prehistoric, but its age is uncertain. Some additional material was also found scattered down the terrace scarp north of the main concentration; included are six plain ironstone sherds, one porcelain sherd (possibly a porcelain doll fragment), and a chert biface thinning flake.

In summary, this material presumably represents a small homestead or outbuilding dating around 1880. The site, 41 GD 48, is registered with the Texas Archeological Research Laboratory, but no further field work is recommended because there is 1 ittle remaining cultural material.

A few isolated finds were noted during the survey. A single isolated chert flake was found in the post oak woodland near the center of the spoit disposal area, northwest of the old fence 1 ine, somewhere between stations $72+00$ and $80+00$. Widely scattered chert $f 7$ akes were seen in several places on the Lissie terrace scarp due south of Berger Bluff, probably indicating sporadic use of this area associated with occupation of Berger Bluff during the Archaic or Late Prehistoric. A small surface collection from this area was made.

The south end of the spoil disposal area, fronting on Turkey Creek, is relatively close to a site (41 GD 26, Fox and Hester 1976:33-34) reported by the phase 1 survey, but no evidence of this site was seen in our survey area.

\section{Survey of Alternate Flume Route 2 (Downstream) and Backhoe Testing at $41 \mathrm{G} B 1$}

The upstream alternate route l, originally considered in planning, was omitted from this project. Alternate route 2 is a more easterly alternate route for the Coleto Creek outfa11, leaving the original proposed route at sta. $88+00$ and entering Coleto Creek about $180 \mathrm{~m}$ downstream from the eastern edge of Area $A$ at the Berger B1uff site, and an estimated 10-25 m upstream from the approximate western edge of 41 GD 31 . This route was examined on August 16; nothing was found on the surface except a small scatter of chert 
flakes exposed in a shal10w gul1y in the Lissie terrace scarp about $120 \mathrm{~m}$ south of Area A at Berger Bluff. Six flakes or flake fragments were collected; no other cultural debris was noted.

The site designated 41 GD 31 has been known to Victoria avocational archaeologists for many years. It 1 ies in a thick deposit of Holocene postBeaumont sediments somewhat 1 ike that exposed at Berger Bluff. At this location, the surface of the post-Beaumont terrace 1 ies at an average elevation of about 98.5 to 99 feet MSL, and is approximately delimited from the Lissie terrace by the 100-foot contour 7 ine. Ed Vogt of Victoria has reportedly collected a Late Paleo-Indian Plainview point from this site. The site was visited by CAR survey teams in 1975 and again in 1977 when a shove 1 test was dug from the terrace surface to a depth of $1.3 \mathrm{~m}$, finding on $1 \mathrm{y}$ sterile deposits. The site was revisited in December 1979 and January 1980 during excavations at the bench area of Berger Bluff. During the 1 atter visit, in 30 minutes' collecting time, 145 pieces of chipping debris, three cores ( $F i g .3, j$ ), five fire-cracked chert fragments, three unaltered chert cobbles/pebbles (manuports), two smal1 unidentified bone fragments, a possible Angostura point made of chalcedony (Fig. 3,1), over 41 mussel she 11 valves (tentatively identified as 21 Amblema plicata. Fig. 3,k; three Cyrtonaias tampicoensis, Fig. 3,m; two Lampsilis sp., Fig. 3,n; 15 unidentified, and various fragments), and a smal1 fossilized plant fragment were collected. Mussel shel1s were very abundant, more so than is indicated by the amount collected; Rabdotus and other snails were observed but not collected. The possible Angostura point is leaf-shaped, with a more constricted haft element than is typical of the type, and 1 acks edge smoothing. Flaking is somewhat irregular, and the specimen has pronounced longitudinal curvature. It resembles somewhat a specimen from the JohnstonHel Ter site (Birmingham and Hester 1976:Fig. 4,a) and another from San Patricio County (Chandler 1982:Fig. 2,C). Turner and Hester (1985) estimate dates of 8500-8000 B.P. for Texas Angostura points, a 1 though the type is poorly dated except at the Wilson-Leonard site.

A11 of this material was derived from a chocolate brown, clay-rich stratum about half a meter or more in thickness, very similar in appearance to stratum 3 at Berger Bluff, the most distinctive depositional unit at the site and one which serves as a marker for the top of the bench deposits. In 1979, a long transit shot from the bench area at Berger Bluff to the base of this stratum gave a reading of $93.26 \mathrm{~m}$ expressed in terms of the Berger B1uff primary datum. By comparison, the base of stratum 3 over the bench deposits at Berger Bluff averages about $93.00 \mathrm{~m}$. The similarity in elevation, thickness, lithology, and content suggests these units may be stratigraphical1y correlated at 41 GD 30 and 41 GD 31.

Since filling of the reservoir had drowned this stratum by the time the Flume No. 3 project was done, it was of course no longer possible to measure directly its depth. The phase 1 survey team had estimated that this stratum 1 ay three to four meters below the post-Beaumont terrace surface, but its depth was not actually measured. Based on the single transit shot obtained in 1979, however, I believe the top of the stratum actually 1 ies about $5.8 \mathrm{~m}$ below the surface, or at about 79.5 feet MSL. This estimate is based in part on transit work done for the present project and on examination of the twofoot contour GBRA project maps, which were not available during the earlier 
Figure 3. Artifacts from 41 GD 30, 41 GD 31, and 41 GD 48.

From the surface, 41 GD 48 :

a, plain ironstone rim sherd;

b, plain ironstone footring sherd;

$c, d$, aqua bottle base sherds;

e, pressed glass kerosene lamp chimney sherd;

$f, g$, cast iron fragments;

$h$, brass harness rivet;

i, iron rod.

From outcrop of buried cultural stratum at 41 GD 31 (collection made in 1980):

j, chert cobble core;

$k$, Amblema plicata, right valve;

1, Angostura point (opaqued for photography);

$m$, Cyrtonaias tampicoensis, right valve;

n, Lampsilis sp., right valve.

Artifact from west profile, backhoe trench 4 at 41 GD 30B:

o, unidentified side-notched dart point (arrow indicates impact fracture). 


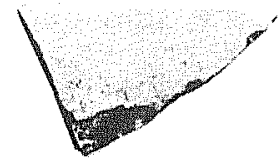

a

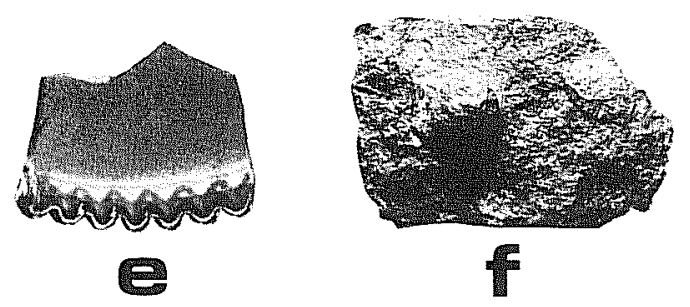

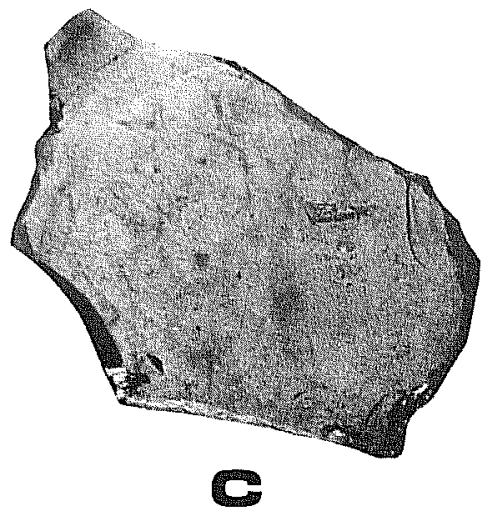
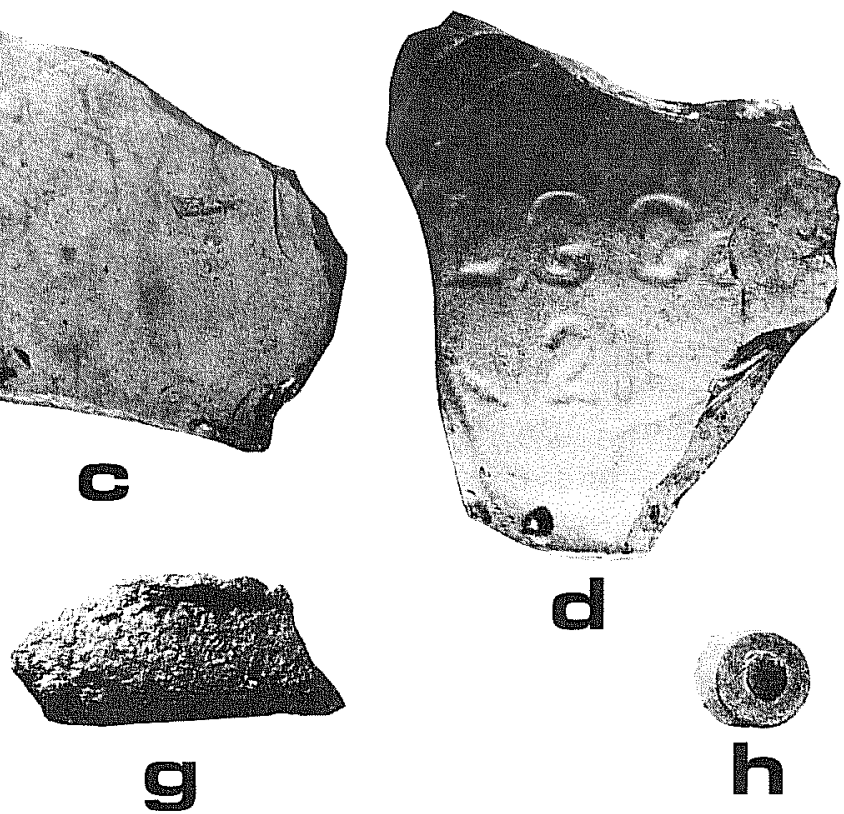

d

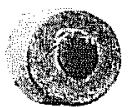

h

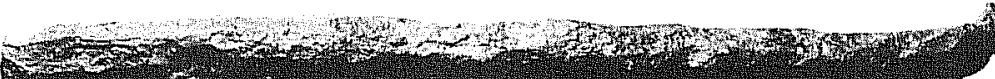

i

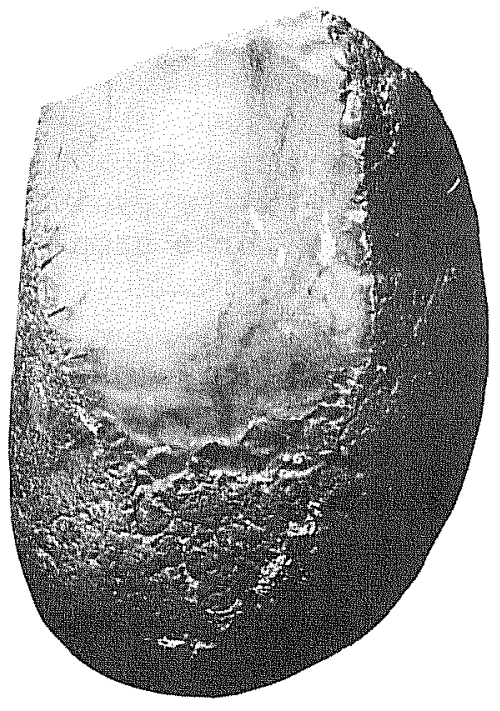

j

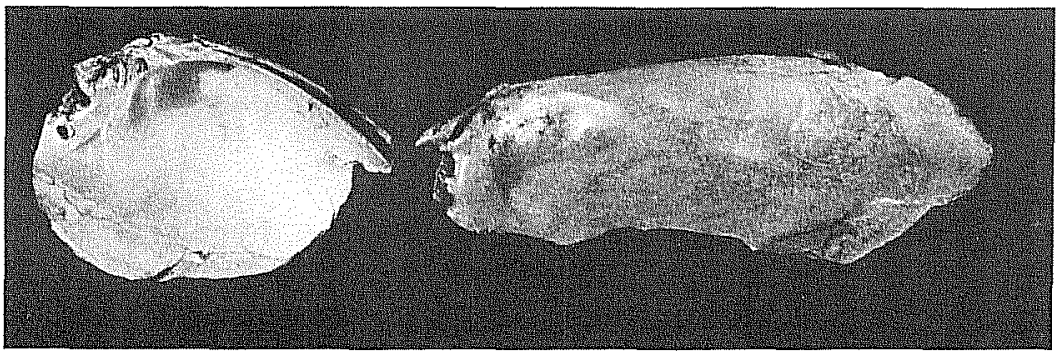

กา
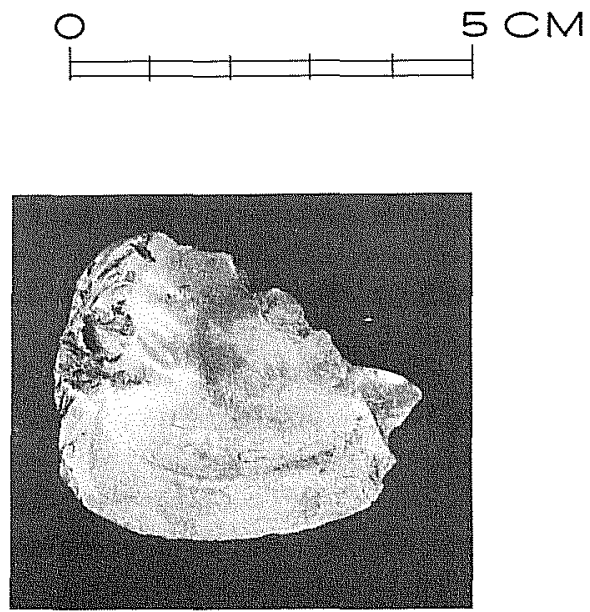

k
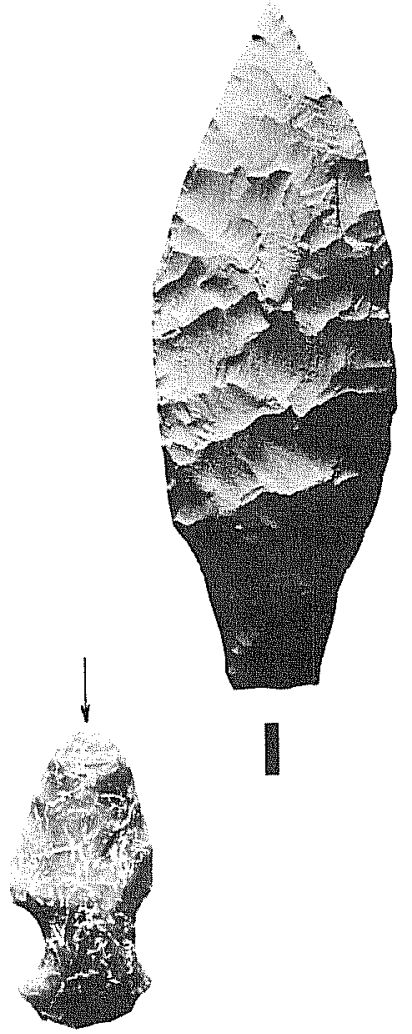
field work but help to pinpoint the elevation of the terrace surface. The elevation of the base of the stratum, however, still hinges on the unknown accuracy of the single transit shot made in 1979.

Two backhoe trenches ( $F$ ig. 2) were dug at the site in an attempt to define the position and extent of the cultural stratum; neither trench was successful in penetrating it. Backhoe trench 1 was oriented due north-south, its north end $16 \mathrm{~m}$ south of the present 1 akeshore, $60 \mathrm{~m}$ due east and $78 \mathrm{~m}$ due north of the GBRA benchmark at turn point 306. GBRA project coordinates for the north end of the trench are approximately N350,680 E2,586160. This trench was expected to fill with water rapidly because of its proximity to the 1 ake, but as it happened, seepage was slow enough to allow the trench to be entered and inspected. The profile was examined for cultural debris (none was observed). Notes were made on the profile, and seven small soil samples were col1 ected at measured depths before the trench was backfilled. This trench is located in the upper portion of the post-Beaumont deposits, but unlike the upper post-Beaumont deposits at Berger Bluff, the entire section exposed in the trench is extreme1y clay-rich. No 1 aboratory data on clay content are available, but visual comparison suggests clay content may run 30 to $40 \%$ or more. The reason for the difference is unknown, although presumably it represents a facies change rather than a stratigraphic difference. In genera1, the sediment becomes less gray and more tan in color with depth, and the clay content in the samples collected appears to diminish with depth. In the trench profile a very tight, compact clay stratum was noted at $2.65 \mathrm{~m}$ depth, although inspection of the sample collected at that level does not seem to indicate a higher clay content than the adjacent samples. Caliche nodules (true accretional caliche nodules with botryoidal growth structure, not Goliad marl clasts) appear in the lowest three samples collected at $3.0 \mathrm{~m}$ and below, suggesting a fluctuating water table and seasonal drying. Snails were noted in the profile from about $3.0 \mathrm{~m}$ and below, probably al1 Helicina orbiculata tropica.

Backhoe trench 1 was located approximately in the center of the site as formerly exposed in the Coleto Creek cutbank, yet no cultural debris was found in the trench. Since the maximum depth of the trench was $3.6 \mathrm{~m}$ (the 1 imit of the backhoe), if the estimated depth of the top of the cultura 1 stratum ( $5.8 \mathrm{~m}$, as discussed) is accurate, then our trench stopped about $2.2 \mathrm{~m}$ above the surface of the cultural stratum. Even if machinery with greater depth capabilities had been available, it is doubtful whether groundwater seepage would have allowed us to enter a deeper trench. As it was, entering the trenches was risky enough. A soil coring device was used in the bottom of the trench in an effort to sample more deep ly, but it would not penetrate more than about $20 \mathrm{~cm}$ of the compact clay. The principal finding from backhoe trench 1 is that the upper $3.6 \mathrm{~m}$ of deposits are cultura11y sterile.

Backhoe trench 2 was excavated on the same alignment as the first trench, with its northern end $38 \mathrm{~m}$ south of the north end of backhoe trench $l_{\text {. }}$ It is $60 \mathrm{~m}$ east of and $40 \mathrm{~m}$ north of the GBRA benchmark mentioned ear 1 ier and is therefore at the contact between the post-Beaumont and Lissie terraces. The sediments exposed in this trench are markedly different from those exposed in the first trench, but it is unclear whether they represent undisturbed Lissie deposits, or colluvium eroded off the Lissie scarp and mixed with 
post-Beaumont alluvium. This trench filled rapidly with groundwater after a fissure between two clay strata was struck, and consequently it was possible to examine only the three meters of deposits near the south end. The deposits here are also culturally sterile. Most of the exposure consists of very 1 ight-colored tan, clay-rich sediment; below about $1.86 \mathrm{~m}$ moderately abundant Rabdotus and Helicina snails were noted; the clay is variegated with blue-gray streaks; above this is a zone with small caliche nodules. Eight soil samples were collected from this trench, and the part above water was examined careful1y: since the 10 wer $60 \mathrm{~cm}$ could not be inspected, the backdirt pile was also checked for cultural debris.

Under the circumstances, it seems doubtful whether any further efforts at machine testing would have been productive. Core drilling might have been tried, but would have proven expensive, and core samples are frequently found to be too smal1 to provide reliable sampling for cultural deposits. Enlarged and deeper trenching might have been attempted, but would also prove expensive, potentially dangerous, and might have been impossible if groundwater conditions were found to worsen markedly below the depth we reached. Under the circumstances, the best and most economical alternative seemed to be to rely on the known extent of the site as plotted in the Coleto Creek cutbank (now underwater) in 1977 and as seen in 1979-1980, and to rely on the 1979 transit shot for an estimate of the depth. These data suggest that on $7 y$ excavations be1ow about 80 feet MSL would disturb the deposits; certain $1 y$ the upper $3.6 \mathrm{~m}$ (11.8 feet) have been shown to be sterile.

As shown on GBRA plans, the outfal1 for alternate route 2 ends at 1 east $10 \mathrm{~m}$ upstream from the western 1 imit of the site as expressed former $1 y$ in the cutbank, so unless the site extends farther to the west than the cutbank exposure suggests, the outfal1 should not impact the site directly, as long as excavation follows the existing plans closely. Whether eddy effects from flume discharge would have any 1 ater impact is unknown. As of 1983, the 1 akeshore at 41 GD 31 had remained quite stable.

\section{Backhoe Testing at $41 \mathrm{GD} 30 \mathrm{~B}$}

Phase 2 testing by the CAR in 1977 at Berger B 1 uff indicated the site is apparent $1 y$ divided into two areas, $A$ and $B$. Area $A$, near the bluff, covers about $2500 \mathrm{~m}^{2}$ and is the area in which al1 the intensive investigations have been concentrated; Area B, farther upslope and to the southwest, covers about $1670 \mathrm{~m}^{2}$ as previously defined. The two areas are separated by a distance of about $25 \mathrm{~m}$ in which four shovel tests uncovered very 1 ittle cultural debris. During the 1977 investigations, five shovel tests and a single $1-\mathrm{m}^{2}$ test pit were dug in Area B. The test pit struck Goliad marl at $1.65 \mathrm{~m}$, while the shovel tests encountered it at variable depths. Since this area was to be impacted by the $f 7 u m e$ outfa 11 , east access road, and drainage ditch, a series of machine tests was placed across the site to define more accurately the boundaries and depth of the archaeological deposits and to verify that the marl deposit encountered in 1977 is bedrock (some cultural debris had been found in pockets in this unit).

Three days were spent digging and recording eight backhoe trenches in and near Area B, on August 9-11, 1983 (Fig. 2). Four trenches (backhoe trenches 
1-4) were spaced in a northwest-southeast row across the approximate center of Area B; a fifth, backhoe trench 8, was joined to the north end of backhoe trench 3, running to the west, specifically to investigate the relationship between deposits in backhoe trenches 3 and 4 . Backhoe trench 5 was placed at the north edge of Area B. Backhoe trench 6 was placed to the south of Area $B$, near an area where some surface cultural debris was observed, and backhoe trench 7 was placed well to the south of the site, but again not far from an area where some surface debris was found. Data on the individual trenches are given in Table 1 and will not be presented in any detail here. In genera 1, trenches were about $10 \mathrm{~m}$ 1ong, al though some were extended to greater lengths to a 110 w better access. Al1 trenches were dug to bedrock (a1though in backhoe trench 4, the depth of the trench prevented removal of loose fill from the floor), and in some cases the machine was able to penetrate somewhat into the bedrock. Because machine time was limited and because our chief goal was to collect dimensional information on Area $B$, it was not possible to record fully each trench with thorough geologic profiles. Instead, selected trenches were profiled, and documentation of the others relied on photography and collection of soil samples for archival storage and possible future studies. A11 trenches, however, were inspected careful1y, and brief notes were taken on the profile in each one. Two trenches (backhoe trenches 2 and 3) were profiled completely (Fig. 4); due to 1 ack of time and the difficulty of viewing the profile in such a deep, narrow trench, backhoe trench 4 was only partial1y profiled: the bottom of the trench and the ground surface were drawn, then notes were taken on a cleaned 50-cm-wide columnar area near the center of the trench. A11 trenches were photographed in both color and black-and-white. The principal findings from the trenching project at Area B can be briefly summarized as follows.

(1) The uppermost bedrock unit at Area B, encountered in the 1977 tests as we11 as our own trenching, is a marl zone representing the Goliad formation. In its purest form it is pure white, with a chalky, 1 ight, talc or diatomite1 ike consistency and texture, with dry weight about $1.3 \mathrm{~g} / \mathrm{m} 1$. Hand specimens contain no visible contaminants, but samples digested in $\mathrm{HCl}$ yield about $13 \%$ of fine and very fine sand (chiefly 2.0 to 3.0 phi on the Wentworth sca 1 e). It occurs as massive, structureless deposits. In most of the trenches, however, the marl occurs as discontinuous masses intermixed with calcareous tan fine sand and fragments of indurated white sandstone. The marl unit is lateral1y rather variable in composition and thickness (ranging from about 40 to $125 \mathrm{~cm}$ thick).

In most of the backhoe trenches an indurated sandstone unit under i ies the marl 1 and forms the floor of most of the trenches; its thickness is unknown. This sandstone varies from a friable, gritty rock to a hard, calichelike, fine-grained rock. In general it closely resembles sandstone exposed in the floor of the ravine west of the site, and about three meters lower in elevation. The latter is a wel1-sorted fine sand, with grain size modes at 2.0 to $2.5,2.5$ to 3.0 , and 3.0 to $3.5 \mathrm{phi}$.

(2) The backhoe testing has confirmed that the previously defined 1 imits of the site (see Fox, Black, and James 1979:Fig. 10) are essentially accurate, but has revealed something that was not apparent before. Over most of Area B, Goliad formation bedrock 1 ies just under the surface, and the archaeological material is confined to a thin deposit overlying it or is 


\begin{tabular}{|c|c|c|c|}
\hline $\begin{array}{l}\text { Backhoe } \\
\text { Trench }\end{array}$ & $\begin{array}{l}\text { Length } \\
(\mathrm{m})\end{array}$ & $\begin{array}{c}\text { Average } \\
\text { Width (m) }\end{array}$ & $\begin{array}{l}\text { Maximum } \\
\text { Depth (m) }\end{array}$ \\
\hline 1 & 10.4 & .85 & 1.27 \\
\hline 2 & 11.9 & .80 & 1.90 \\
\hline 3 & 10.25 & - & 1.55 \\
\hline 4 & 15.0 & .85 & 3.50 \\
\hline 5 & 10.75 & .90 & $\begin{array}{l}1.5(N) \\
1.26(S)\end{array}$ \\
\hline 6 & 9.9 & .85 & 1.47 \\
\hline 7 & 10.0 & .90 & 1.66 \\
\hline 8 & 13.7 & 1.20 & 2.45 \\
\hline
\end{tabular}

Soil

Samples

5 No cultural debris; soil developed on tan fine sand unit overlying marl.

$6 \quad$ No cultural debris; soll developed directly on marl unit which overlies fine sand unit with Goliad sandstone fragments.

Soll A horizon $50 \mathrm{~cm}$ thick, with chert flakes, Helicina and Rabdotus shells, musse 1 she 11 fragments, small chert pebbles, occasional small chert cobbles overlying tan fine sand unit, then mixed with marl and sandstone over indurated sandstone; west wall profiled; backhoe trench 8 joins north end.

Entire profile consists of stratified fine sand, becoming more tan and calcareous toward base; presumably represents colluvium but source of sediment not identified; cultural debris discontinuously distributed through entire section; dart point recorded in situ at $1.1 \mathrm{~m}$; indurated sandstone at $3.5 \mathrm{~m}$ at base of trench; stratigraphic section broadly resembles strata 5 and 4 at Area $A$ but relationship is presently unclear.

Backhoe trench and surrounding terrain both slope down to north; cultural debris present in $30 \mathrm{~cm}$ thick soll A horizon; soll developed directly on marl at south end, on tan fine sand at north end.

No cultural debris; soll developed on thin Lissie alluvium $(60 \mathrm{~cm}$ thick) over marl.

No cultural debris; highly organic soll developed on mixed marl and sandstone; cultural debris visible to west near ravine, on surface, but none visible in profile.

No notes taken; joins north end of backhoe trench 3, running west almost to south end of backhoe trench 4 ; dug to clarify relationship between deposits in backhoe trenches 3 and 4; indicates bedrock dips steeply westward, but vertical scarp is lacking; cultural debris is present. 
Figure 4. Profiles of Backhoe Trenches 2 and 3 at 41 GD 30B. Numbered squares are soil samples. Circled numbers represent pedogenic/stratigraphic units. Elevations are in terms of arbitrary excavation datum of $100.00 \mathrm{~m}$ used at Area $A_{\text {. }}$

Backhoe trench 2:

1. A zone, crumbly texture, irregular peds, 1 ight gray silty clay (10YR 6/1.5) with rootlets and smal1 calcareous nodules; lower contact irregular and gradationa 1;

2. pure white marl (1OYR 9/1) variegated with 1 ight brownish gray (10YR 6.5/1.5) vertical root molds and irregular horizonta 1 , vertical, or round patches; occasional small pepper flakelike manganese concretions; no visible lamination or stratification; lower contact is irregular, but fairly clear:

3. zone of indurated white (Goliad?) sandstone, apparentiy the same as that in the floor of the trench; shown rather schematical1y, not we11 differentiated from the mar1;

4. 1ight gray brown fine sand (10.5YR 7.5/2), massive, ca 1 careous appearing (probably decomposed Goliad sandstone), containing occasional scattered Goljad sandstone nodules up to $3 \mathrm{~cm}$ in diameter;

5. indurated white Goliad sandstone bedrock (10YR 8.5/1) forming floor except where penetrated at north end.

Backhoe trench 3:

1. A zone, medium gray (10YR 4.5/1.5), friable, crumbly texture, clayey silt with rootlets, chert flakes. Helicina orbiculata tropica and Rabdotus sp. she11, musse 1 she 11 fragments, smal1 chert pebbles; lower contact fairly regular, somewhat gradationa 1;

2. 1ight $\tan$ silt (10YR 7.5/2.5), relatively homogeneous except for widely scattered mottles of white chalky marl averaging about 1-2 cm in diameter; no cultural debris or snails present; has occasional smal1 patches (a few millimeters in diameter) that are $7.5 Y R \quad 8 / 5$;

3. mixed white chalky marl and Goliad sandstone (10YR 9/1); floor is indurated Goliad sandstone. 


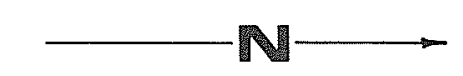

\section{BACKHOE TRENCH 2}

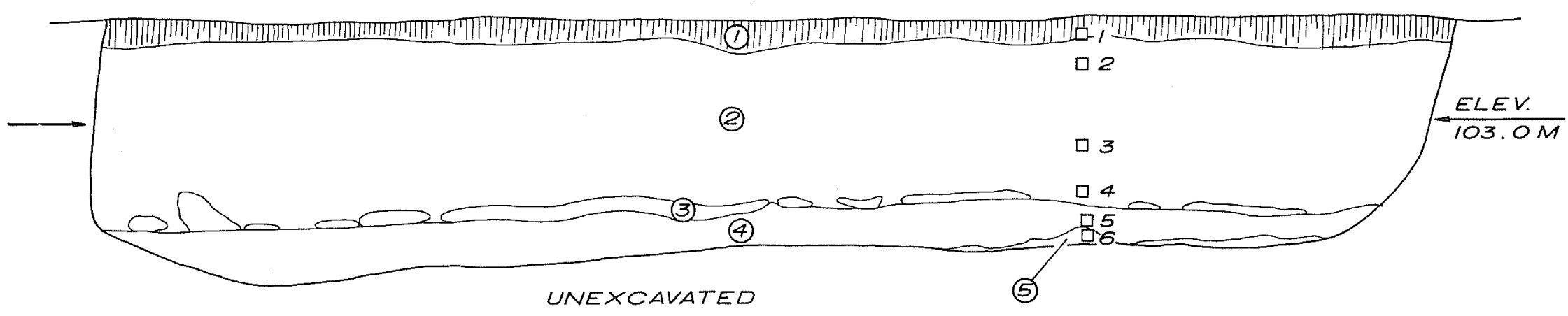

\section{BACKHOE TRENCH 3}

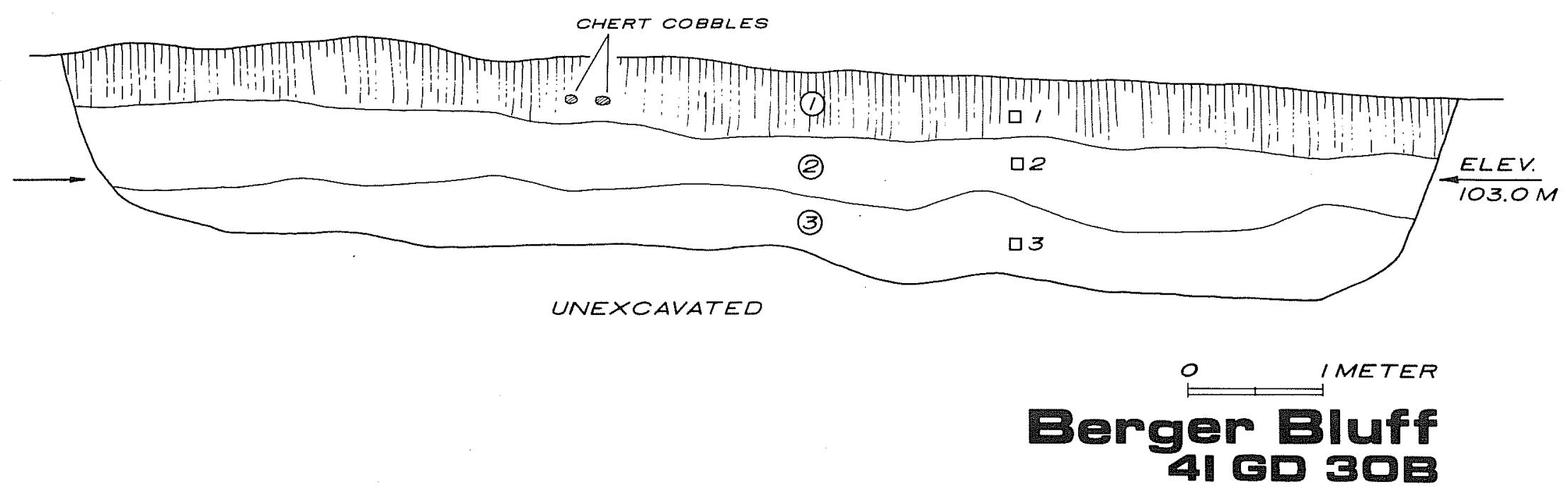


restricted to a surface scatter; but along the western margin of the site, the bedrock plunges rather sharply and some deep archaeological deposits are present. In particular, the bedrock drops rapidly between backhoe trenches 3

and 4. Traversing southeast to northwest across Area B, for example, backhoe trench 2 contains no archaeological deposits; backhoe trench 3 contains about $50 \mathrm{~cm}$ of archaeological deposits (confined here to the $A$ zone in the soil profile); and backhoe trench 4 contains about $3.6 \mathrm{~m}$ of archaeological deposits (Fig. 5). Evidently a thick accumulation of sediment has taken place here along the eastern edge of the ravine, mantling a somewhat sloping bedrock scarp. Cultural debris was found distributed discontinuously, essentially throughout the stratigraphic section here. The sediment consists of gray to tan, apparently we11-sorted fine sand, becoming less gray and more tan in color with depth, and with diminishing quantities of cultural debris with depth. At about $1.9 \mathrm{~m}$ and below is a zone with Goliad marl nodules and masses. The geologic origin of this fine sand deposit is unknown; presumably it is colluvial, at least in the area of backhoe trench 4 where such a thick accumulation is evident, yet no source area for such colluvium can be identified. Because of its elevation (the base of backhoe trench 4, although over three meters deep, nevertheless rests at about 99 to 100 feet MSL), it presumably cannot be Holocene Coleto Creek alluvium; an aeolian or ravine outwash origin also seems unlikely. The number of dart points collected at Area B (Fox, B 1 ack, and James 1979:47,ff) and the 1ack of Late Prehistoric material perhaps suggest this deposit may be somewhat older than the surface of the post-Beaumont terrace at Area $A$, but this is mostly conjectural. A single side-notched dart point was found in situ at $1.1 \mathrm{~m}$ in backhoe trench 4 (Fig. 3,0).

In summary, essential1y a 11 of 41 GD $30 \mathrm{~B}$ would be impacted by construction of the flume, access road, and drainage ditch as originally planned. Over much of the area the deposits that would be destroyed are thin and unstratified; in some parts of the site, cultural debris is confined to the soil developed directly on bedrock. However, a thick package of stratified sediments is present along the northwest side of the site, 1 ining the steep 1 y sloping ravine bank. These deposits would be completely removed by excavation of the flume as originally planned, and archaeological excavations to mitigate this loss would be necessary.

\section{SUMMARY AND MANAGEMENT RECOMMENDATIONS}

The following observations have resulted from survey and machine testing done for the Flume No. 3 project:

(1) Pedestrian survey of the Flume No. 3 right-of-way located one previously unrecorded historic site (41 GD 48), marked by a smal1 scatter of 1ate 19thcentury historic artifacts and sandstone blocks, probably remnants of house or crib piers. No further field work is recommended.

(2) Alternate route 2 (downstream route) wi 11 not impact 41 GD 30 and, on the basis of the best available information, should not impact 41 GD 31 . Machine testing at the latter site failed to reach the top of the buried cultural stratum there, but if the 1 imits of the stratum as exposed in the Coleto Creek cutbank in 1977 are an accurate indication of its western 

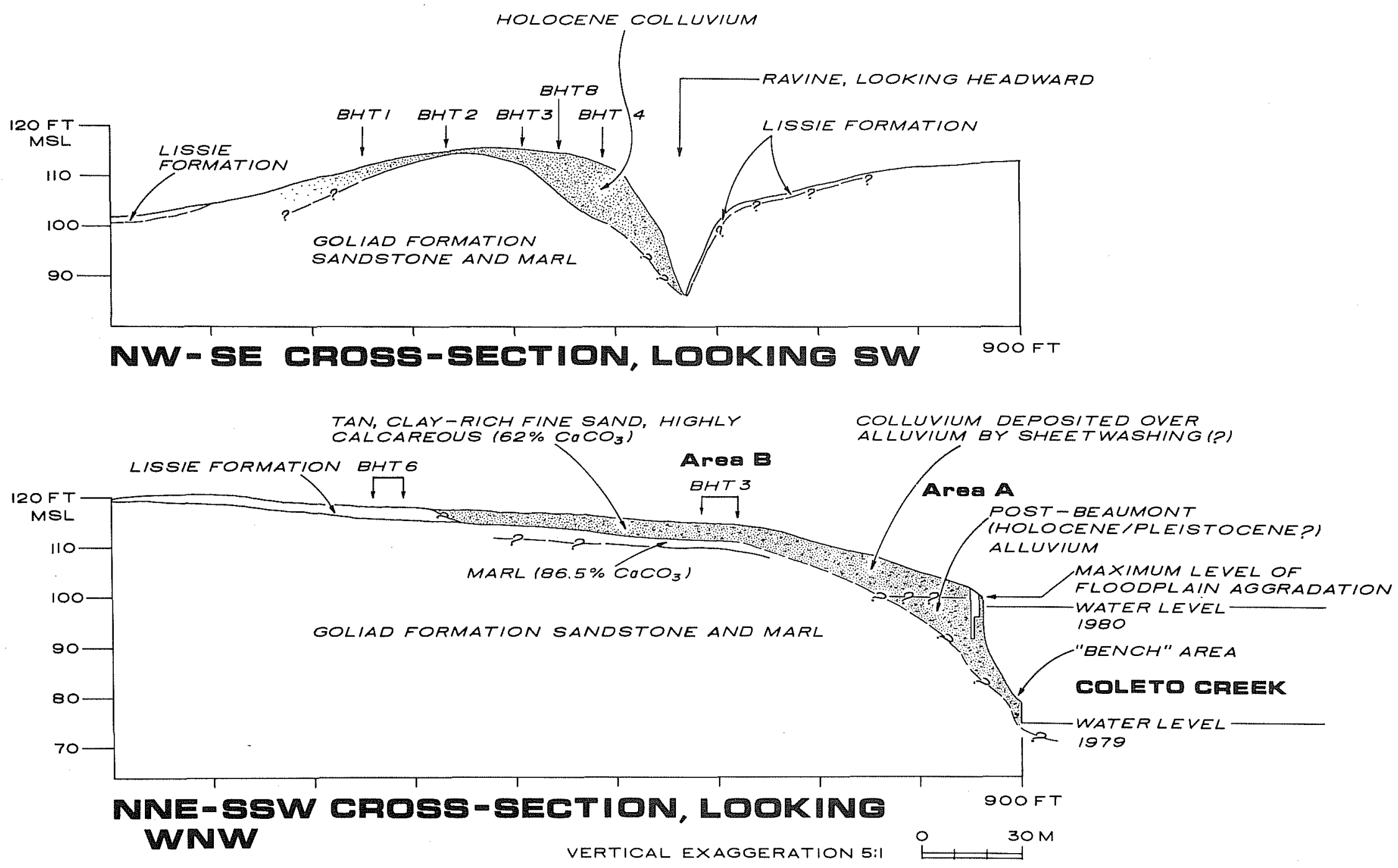

Figure 5. Cross Sections of Geologic Units at the Berger Bluff Site (41 GD 30), Based on Backhoe Trenching and Hand Excavation. The lower section is somewhat similar to Figure 3 in Brown (1983) but is based on much more data and is therefore more accurate. Elevations represent feet above mean sea $1 e v e 1$. The 1979 excavation block is shown near the edge of the bluff. Note vertical exaggeration. 
extent, the flume outfal1 should 1 ie just outside the 1 imits of the site. Of the two alternative routes, route 2 is considered the least 1 ikely to damage the archaeological sites in the area, and is therefore the preferred route from that viewpoint.

(3) The primary Fiume No. 3 route, which follows the existing ravine to Coleto Creek, would impact essential1y a11 of 41 GD $30 \mathrm{~B}$ and would destroy the thick section of stratified archaeological deposits located along the east side of the ravine. Further archaeological excavations would be necessary to mitigate this impact. In addition, construction of a caisson or dike at the mouth of the ravine to allow the outfall to be built would probably damage $41 \mathrm{GD} 30 \mathrm{~A}$ as we11, depending on the location of the dike and how it is built. The primary route is the least desirable in terms of avoiding impact on the archaeological resources.

\section{REFERENCES CITED}

Birmingham, W. W. and T. R. Hester

1976 Late Pleistocene Archaeological Remains from the JohnstonHeller Site, Texas Coastal Plain. In Papers on Paleo-Indian Archaeology in Texas: I. Center for Archaeological Research, The University of Texas at San Antonio, Special Report 3.

Brown, D. 0 .

1983 The Berger Bluff Site (4l GD 30A): Excavations in the Upper Deposits, 1979. Center for Archaeological Research, The University of Texas at San Antonio, Archaeological Survey Report 115.

Chandler, C. K.

1982 Paleo-Indian Projectile Points from San Patricio County, Texas, Texas Coastal Bend. La Tierra 9(3):26-33.

Dibble, D. S.

1967 Excavations at Arenosa She1ter 1965-1966. Texas Archeological Salvage Project, The University of Texas at Austin.

Fox, A. A., S. L. Black, and S. R. James

1979 Intensive Survey and Testing of Archaeological Sites on Coleto Creek, Victoria and Goliad Counties, Texas. Center for Archaeological Research. The University of Texas at San Antonio, Archaeological Survey Report 67. 
Fox, A. A. and T. R. Hester

1976 An Archaeological Survey of Coleto Creek, Victoria and Goliad Counties, Texas. Center for Archaeological Research. The University of Texas at San Antonio, Archaeological Survey Report 18.

Fox, A. A. and K. Livingston

1979 Historical, Architectural and Archaeological Investigations at the Steiner-Schob Complex, Victoria County, Texas. Center for Archaeological Research. The University of Texas at San Antonio, Archaeological Survey Report 52.

Fox, D. E.

1979 Archaeological Investigations of Two Prehistoric Sites on the Coleto Creek Drainage, Goliad County, Texas. Center for Archaeological Research. The University of Texas at San Antonio, Archaeological Survey Report 69.

Potter, D. and L. Spencer

1980 An Examination of Prehistoric Human Remains at the Victoria Regional Wastewater Treatment Plant, Victoria County, Texas. Center for Archaeological Research, The University of Texas at San Antonio, Archaeological Survey Report 94.

Scott, R. F. IV

1982 Excavations at Sites 41 LK $31 / 32$ and 41 LK 202 in the Choke Canyon Reservoir, South Texas. Center for Archaeological Research, The University of Texas at San Antonio, Choke Canyon Series 8.

Taylor, A. J.

1985 Archaeological Survey of a Proposed Riverside Park Trail at the Victoria Municipal Park, Victoria. Texas. Center for Archaeological Research. The University of Texas at San Antonio, Archaeological Survey Report 155.

Toulouse, J. H.

1971 Bott1e Makers and Their Marks. Thomas Ne1son, Inc, Camden, New Jersey.

Turner, E. S. and T. R. Hester

1985 A Field Guide to Stone Artifacts of Texas Indians. Texas Monthly Press, Austin. 
